Trademark Notice: Product and corporate names may be trademarks or registered trademarks and are used only for explanation and to the owner's benefit, without intent to infringe.

For advertising rates and deadlines, contact the AECT offices, 812-335-7675.

Subscription information: TechTrends is published six times per year by Springer Science+Business Media, LLC. Volume 57 (6 issues) will be published in 2013

ISSN: 8756-3894 (print version)

ISSN: 1559-7075 (electronic version)

Subscription Rates, Orders, Inquiries: Please contact our Customer Service department for the latest rates and information: The Americas (North, South, Central America, and the Caribbean):

MAIL: Journals Customer Service

233 Spring Street

New York, NY 10013-1578, USA

TEL: 800-777-4643; 212-460-1500 (outside North America) FAX: 201-348-4505

E-MAIL: journals-ny@springer.com;

servicio-ny@springer.com (Central and South America)

Outside of the Americas:

MAIL: Journals Customer Service

Springer Customer Service Center

Haberstrasse 7

69126 Heidelberg, GERMANY

TEL: 49-6221-345-4303

FAX: 49-6221-345-4229

E-MAIL: subscriptions@springer.com

Change of Address: Allow six weeks for all changes to become effective. All communications should include both old and new addresses (with zip codes) and should be accompanied by a mailing label from a recent issue.

Back Volumes: Prices for back volumes are available on request.

Microform Editions: Available from:

University Microfilms International, 300 N. Zeeb Road, Ann Arbor, MI 48106, USA

SpringerAlert Service: The SpringerAlert service is an innovative, free-of-charge service that notifies users via e-mail whenever new SpringerLink articles and journals become available, and automatically sends the table of contents and direct links to the abstracts of a new issue of a journal in SpringerLink. Register for the SpringerAlert service at http://www.springerlink.com/alerting

(C)2013 Association for Educational Communications and Technology

Periodicals postage paid at New York, New York and additional mailing offices.

Postmaster: Send address changes to TechTrends, Springer, 233 Spring Street, New York, NY 10013, USA.

\title{
AECT 2012: Louisville Convention Reflections
}

\author{
By Marcus D. Childress, AECT President
}

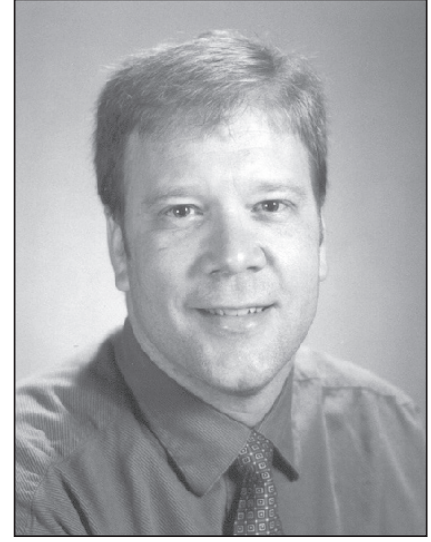

Marcus D. Childress

$\mathbf{W}$ ith the AECT 2012 Louisville Convention behind us, we now have an opportunity to reflect upon our many experiences in Louisville. With the "Frankenstorm" (Hurricane Sandy) bearing down upon the US, our members showed amazing dedication and persistence, waiting through hours of telephone holds, rescheduling flights and transportation plans, and some eventually driving long distances through sleet and snow; all so that they could join us in Louisville! Once again, the Galt House Hotel provided a comfortable setting for our members to their expertise, meet new colleagues, and catch-up with old friends. Our keynote speakers shared timely and inspiring messages. In his presentation, World Class Learners: Educating Creative and Entrepreneurial Students, Dr. Yong Zhao discussed his view of a future-oriented education that aims to prepare students as globally competent and creative entrepreneurs. In addition, he discussed the role technology plays in creating and delivering such an education. In his keynote presentation, The Changing Landscape of
Higher Education, Dr. Malcolm Brown explored developments in higher education over the past decade, the period of rapid evolution that continues and the technology that enables them. In his closing keynote, The Mind, the Brain, and Quality Control in Educational Technology, Dr. Daniel Willingham offered a principled look at the relationship of neuroscience and technology, and suggested ways that AECT members might play an important role in conversation that drives the direction of education. Our divisions provided a plethora of session and activities, building a convention program with a wide spectrum of opportunities for sharing and networking with colleagues. The 2012 convention planning team, comprised of division and affiliate representatives, should be commended for its countless hours of planning and preparation. However, the planning never stops. Our 2013 convention planning team is already at work on the Anaheim convention. Let's keep our fingers crossed that our meeting in Anaheim will be blessed with wonderful weather and uneventful travel experiences! 